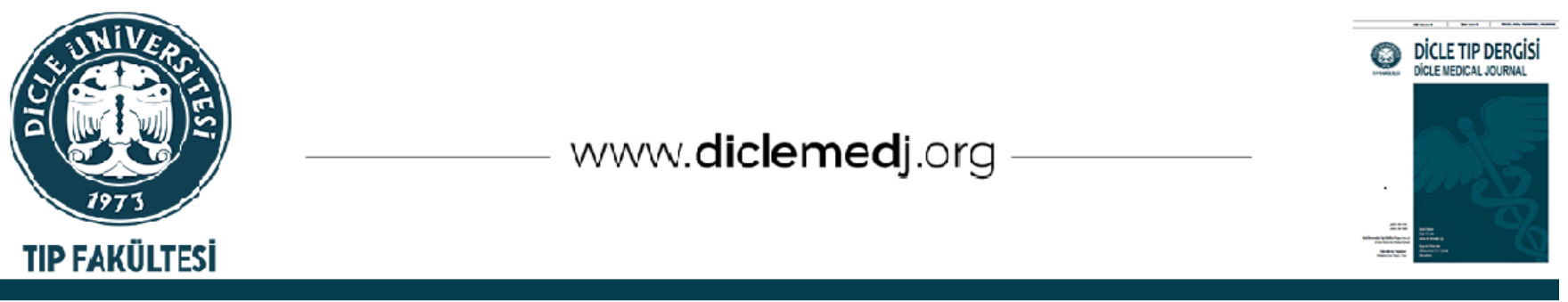

Original Article / Özgün Araştırma

\title{
Intravenous Thrombolytic Therapy for Acute Ischemic Stroke: Experiences of a Tertiary Hospital in Turkey
}

\author{
Murat Yilmaz ${ }^{(D)}$, Handan Teker ${ }^{i D} 1$, Merve Onerli Yener ${ }^{i D}{ }_{1}$, Edip Gultekin ${ }^{(i D}$, \\ Muhammed Nur Ogun ${ }^{D} 1$
}

1 Department of Neurology, Bolu Izzet Baysal University, Bolu, Turkey

2 Department of Neurology, Nusaybin State Hospital, Mardin, Turkey

Received: 28.10.2020; Revised: 27.01.2021; Accepted: 31.01.2021

\begin{abstract}
Objective: The aim of this study is to retrospectively collect the data of 95 patients with ischemic stroke who received intravenous (IV) tissue plasminogen activator (tPA) therapy between 2015 and 2019 in our clinic, to present the experiences of our clinic.

Method: The data of the patients, who applied to our clinic with the diagnosis of acute ischemic stroke between 2015 and 2019, who received thrombolytic therapy, were reviewed retrospectively. General socio-demographic data, clinical features, National Institute Health Scale Scores (NIHSS), Alberta Stroke Program Early Computed Tomography (ASPECT) scores, symptom-to-door, door-to-needle, and symptom-to-needle times, treatment-related complications and Modified Rankin Scores (mRS) at the third month after treatment were evaluated.

Results: Procedure-related major or minor bleeding complications developed in $18 \%$ of our patients who received tPA therapy. The mortality rate was $15 \%$ and $6.3 \%$ of these were caused by cerebral hemorrhage due to treatment complications and $8.7 \%$ were due to other systemic complications. Logistic regression analysis revealed that only the ASPECT score from factors that we found to be effective on the risk of developing complications was a highly effective factor in the development of complications ( $p=0.034$, OR: 2.131).

Conclusions: This study has shown that our results are generally compatible with the literature. Although there is an increase in the number of patients receiving tPA in our clinic every year, we aim to increase awareness of this therapy clinically and to expand the use of IV thrombolytic therapy in selected patients.
\end{abstract}

Keywords: tissue plasminogen activator, ischemic stroke, Modified Rankin Score

DOI: $10.5798 /$ dicletip.887410

Correspondence / Yazışma Adresi: Murat Yilmaz, BDepartment of Neurology, Bolu Izzet Baysal University, 14030 Merkez/Bolu, Turkey e-mail: dryilmazmurat@gmail.com 


\section{Akut İskemik İnmede İntravenöz Trombolitik Tedavi: Türkiye'deki Üçüncü Basamak Bir Hastanenin Deneyimleri}

Öz

Giriş: Bu çalışmanın amacı, kliniğimizde 2015-2019 yılları arasında intravenöz (IV) doku plazminojen aktivatör (tPA) tedavisi alan 95 iskemik inmeli hastanın verilerini retrospektif olarak toplamak ve kliniğimizin deneyimlerini sunmaktır.

Yöntemler: 2015-2019 yılları arasında akut iskemik inme tanısı ile kliniğimize başvuran trombolitik tedavi alan hastaların verileri retrospektif olarak incelendi. Genel sosyo-demografik veriler, klinik özellikler, National Institute Health Scale Score (NIHSS), Alberta Stroke Program Early Computed Tomography (ASPECT) skorları, kapı-iğne zamanı, semptom-iğne zamanı, tedaviye bağlı komplikasyonlar ve tedaviden sonraki üçüncü aydaki Modifiye Rankin Skoru (mRS) değerlendirildi.

Bulgular: tPA tedavisi alan hastalarımızın \%18'inde işleme bağlı majör veya minör kanama komplikasyonları gelişti. Mortalite oranı \%15 idi ve bunların \%6,3'ü tedavi komplikasyonlarına bağlı beyin kanamasından ve \%8,7'si diğer sistemik komplikasyonlardan kaynaklanıyordu. Lojistik regresyon analizi, komplikasyon gelişme riski üzerinde etkili bulduğumuz faktörlerden sadece ASPECT skorunun komplikasyon gelişiminde oldukça etkili bir faktör olduğunu ortaya koymuştur ( $\mathrm{p}=0,034$, OR: 2,131).

Sonuç: Bu çalışma, sonuçlarımızın genel olarak literatür ile uyumlu olduğunu göstermiştir. Kliniğimizde her yıl tPA alan hasta sayısında artış olmasına rağmen, klinik olarak bu tedavinin farkındalığını artırmayı ve seçilmiş hastalarda IV trombolitik tedavi kullanımını yaygınlaştırmayı hedefliyoruz.

Anahtar kelimeler: doku plazminojen aktivatörü, iskemik inme, Modifiye Rankin Skoru.

\section{INTRODUCTION}

Ischemic cerebrovascular disease is a condition that accounts for about $80 \%$ of all stroke syndromes and causes serious mortality and morbidity. It is a systemic disease associated with the highest rate of morbidity among all age groups worldwide ${ }^{1}$. The size of the affected brain tissue varies depending on the localization of the occluded artery and vascular collateralization. The main treatment objective in the acute period of the disease is to open the occluded artery in the shortest possible time, to provide recanalization and to minimize neuronal death ${ }^{2}$. Time is the key factor in this treatment. The sooner the recanalization is achieved, the more neuronal survival is achieved and the success rate in treatment increases. Ischemic penumbra refers to the area that can restore functions following a vascular occlusion and is the main target region for the treatment of an ischemic event ${ }^{3}$. Long-term follow-ups after stroke have shown that the majority of patients need someone else's help for carrying out self-care and daily activities, and both patients and their relatives are restricted socially. Therefore, this disease causes loss of labor and financial damage to the country.

There have been important improvements in the treatment of acute ischemic stroke in the past two decades. Intravenous (IV) tissue plasminogen activator (tPA) therapy is the first and perhaps most important one of these improvements. In the National Institute of Neurological Disorders and Stroke (NINDS) study conducted in 1996, the tPA therapy has been proven to be effective in patients presenting to the hospital in the first three hours after ischemia for the first time. Then, this therapy has started to be used widely all over the world4. In the European Cooperative Acute Stroke Study III (ECASS-III) study published in 2008, the time window previously determined as three hours to apply IV tPA was extended to four and a half hours5. Although there are many studies revealing the positive effects of IV tPA 
on both morbidity and mortality, its application is still not exactly at the desired level worldwide. For instance, IV tPA could be used in only $3.5 \%$ of all patients with acute ischemic stroke in 2008 in the USA. Although the official numbers in Turkey are not known, the IV tPA application is known not to be widely used and studies aiming at creating awareness in this regard should be done in Turkey ${ }^{6,7}$. On the other hand, the number of studies showing that tPA therapy has been recently used more widely in many clinics in Turkey and compiling the clinics' experiences on thrombolytic treatment has been increasing gradually-12. In our clinic, tPA treatment has been applied since 2015 and there is an increase in the number of patients receiving tPA therapy every year. The aim of this study was to retrospectively collect the data of 2019 patients with ischemic stroke who received IV tPA therapy between 2015 and 2019 in our clinic, to compare the obtained data with the literature information, and to present the experiences of our clinic.

\section{METHODS}

This retrospective study was carried out in the neurology clinic of Bolu Training and Research Hospital. Among the patients who were admitted to our clinic with the diagnosis of acute ischemic cerebrovascular disease between 2015 and 2019, data of those who were eligible for IV thrombolytic therapy and received tPA therapy were scanned retrospectively. Sociodemographic data such as age, gender, height, and weight, symptoms at the time of admission, the time between the onset of stroke symptoms and admission to hospital (symptom-to-door time), the time between admission to hospital and initiation of treatment (door-to-needle time), neurological examination findings, and laboratory findings (hemogram, glucose, urea, creatinine, liver function tests, kidney function tests, etc.) were recorded. Before starting thrombolytic therapy, computed tomography (CT) was performed in all patients and where necessary, CT angiography or magnetic resonance (MR) angiography tests were performed for vascular imaging. Alberta Stroke Program Early CT Scored (ASPECTS) of all patients were calculated. In this scoring system, hypodensities in CT are counted. Each affected area causes a one-point deduction from a total of 10 points ${ }^{13}$. National Institutes of Health Stroke Scale (NIHSS) scores of all patients were also calculated and recorded. This is a reliable neurological scale consisting of 11 categories and 15 subtitles. It is evaluated quickly and is compatible with infarct volume. The scoring range is 0 to 42 points. The NIHSS score and clinical examination findings are correlated; clinical deterioration increases as the score increases ${ }^{4}$.

Patients with contraindications for thrombolytic therapy were excluded from the study. Conditions contraindicated for tPA were determined according to the guidelines on IV tPA administration for acute ischemic stroke that is based on the American Heart Association IV tPA therapy guideline published by the Turkish Neurological Society brain vascular diseases study group ${ }^{14}$. During the hospitalization of all patients, posterioranterior (PA) chest x-ray, echocardiography (Echo), electrocardiogram (ECG), and carotid/vertebral artery Doppler ultrasonography (USG) were performed. If any, abnormalities in these examinations were noted. Modified Rankin scales (mRS), measured three months after patients were discharged, were evaluated. The mRS is used to evaluate the patient's dependence on others and functional recovery. It is evaluated over a total of six points. A score of three and above means that patients continue their lives dependent on others ${ }^{15}$.

Patients who had no contraindications for treatment or their relatives were informed about the benefits and possible complications of the therapy and their consent was obtained. The tPA was administered at a dose of $0.9 \mathrm{mg} / \mathrm{kg}$ 
and $10 \%$ of the total dose was given as a rapid IV injection. The remaining dose was given as an infusion in a way to be finished within one hour.

\section{Statistical Analyses}

Statistical analysis was performed by using SPSS Version 21. Whether data followed normal distribution was investigated by using Shapiro Wilk test. Continuous data were expressed as mean and standard deviation or median (minimum-maximum) according to the distribution status. Normally distributed parameters (times, LDL, total cholesterol and MCV) were evaluated by independent variables t-test. Mann Whitney $U$ test was used to compare parameters that did not follow a normal distribution. Chi-square and Fisher Exact test were used to compare categorical data. A p value of $<0.05$ was considered statistically significant.

\section{RESULTS}

The mean age was $71.50 \pm 13.89$ years. Of the patients, 38 were male and 57 were female. The mean door-to-needle time and symptom-toneedle time of the patients were $89.63 \pm 48.29$ minutes and $137.32 \pm 52.44$ minutes, respectively. The mean NIHSS score was 12.94 \pm 4.80 . The mean ASPECT score was $8.57 \pm 1.50$.

There were 95 patients in total without any contraindications for thrombolytic therapy. The mean age of the patients was $71.50 \pm 13.89$ years. Of the patients, $38(40 \%)$ were male and $57(60 \%)$ were female. Two (2\%) patients had posterior cerebral artery (PCA) occlusion, eight (9\%) patients had vertebral artery occlusion, three (3\%) patients had basilar artery occlusion, five $(6 \%)$ patients had anterior cerebral artery (ACA), one patient had common carotid artery (CCA) occlusion, and 77 (80\%) patients had middle cerebral artery (MCA) occlusion. When risk factors for the ischemic cerebrovascular disease were examined, 54 patients (58\%) had hypertension (HT), 23 patients (24\%) had diabetes mellitus (DM), 46 patients $(47.5 \%)$ had hyperlipidemia (HL), 38 patients (39\%) had coronary artery disease, 51 patients (56\%) had atrial fibrillation (AF) and 35 patients $(37 \%)$ had heart failure. The mean door-to-needle time was $89.63 \pm 48.29$ minutes (min) and the mean symptom-to-needle time was $137.32 \pm 52.44$ minutes. The mean NIHSS scores of the cases were $12.94 \pm 4.80$, the mean ASPECT score was $8.57 \pm 1.50$ and the mean mRS score at the third month after treatment was $3 \pm 1.82$. An angiographic method was performed in 68 (71\%) patients; 60 of them underwent CT angiography and eight underwent MR angiography.

Of the participants, 51 (53\%) had AF and 37 (40\%) had heart failure. Mitral valve regurgitation was detected in 37 patients and tricuspid valve regurgitation was present in 32 patients. In the images of the carotid vertebral artery system obtained via radiological examinations, no significant stenosis or occlusion was detected in this system in 77 patients whereas there was complete occlusion of the carotid artery in three patients and 15 had carotid stenosis of $50 \%$ or greater.

The mRS assessment of patients on the first day showed that two $(2.2 \%)$ patients had the mRS score of 1 whereas mRS score was 2 in eight $(8.7 \%)$ patients, 3 in 12 patients $(13.0 \%), 4$ in $19(22.8 \%)$ patients, and 5 in 49 patients $(53.3 \%)$. When the mRS scores at the first month were examined, the disability levels of the patients was evaluated to be level 1 in five (5.5\%) patients, level 2 in $15(16.5 \%)$ patients, level 3 in 14 patients (15.4\%), level 4 in 18 (19.8\%) patients, level 5 in 21 patients (23.1\%), and level 6 in 18 (19.8\%) patients. Considering the mRS scores at the third month, the disability degrees of the patients was evaluated to be level 1 in nine (10.3\%) patients, level 2 in 19 (21.8\%) patients, level 3 in 15 (\%17.2) patients, level 4 in eight $(9.2 \%)$ patients, level 5 in nine patients 
(10.3\%), and level 6 in $27(31.0 \%)$ patients (Table I).

Table I: Distribution of the first-day, first-month, and third-month Modified Rankin scores of patients by levels

\begin{tabular}{|lllllll|}
\hline $\begin{array}{l}\text { Modified } \\
\text { Rankin }\end{array}$ & \multicolumn{2}{l}{ 1ST DAY } & \multicolumn{2}{c|}{ 1ST MONTH } & \multicolumn{2}{c|}{ 3RD MONTH } \\
Score & n & \% & n & \% & n & \% \\
\hline $\mathbf{1}$ & 2 & 2.2 & 5 & 5.5 & 9 & 10.3 \\
$\mathbf{2}$ & 8 & 8.7 & 15 & 16.5 & 19 & 21.8 \\
$\mathbf{3}$ & 12 & 13.0 & 14 & 15.4 & 15 & 17.2 \\
$\mathbf{4}$ & 19 & 22.8 & 18 & 19.8 & 8 & 9.2 \\
$\mathbf{5}$ & 49 & 53.3 & 21 & 23.1 & 9 & 10.3 \\
$\mathbf{6}$ & & & 18 & 19.8 & 27 & 31.0 \\
\hline
\end{tabular}

When the effects of systemic diseases, which were the risk factors for ischemic cerebrovascular disease, on mRS scores were compared, the third-month mRS scores of the patients with and without risk factors were similar $(p=0.076$ for DM, $p=0.240$ for HT, $\mathrm{p}=0.435$ for $\mathrm{HL}, \mathrm{p}=0.131$ for CAD, $\mathrm{p}=0.362$ for $\mathrm{HF}, \mathrm{p}=0.323$ for tricuspid regurgitation [TR], $\mathrm{p}=0.546$ for mitral valve regurgitation (MVR), and $p=0.063$ for atrial fibrillation) (Table II). No statistically significant relationship was detected between mRS scores and door-toneedle time, symptom-to-needle time, NIHSS scores at the time of admission, and ASPECT scores $(p=0.203, p=0.302, p=0.595$, and $\mathrm{p}=0.132$, respectively).

The NIHSS scores at the time of admission of patients with AF were statistically significantly higher than patients without AF $(p=0.004)$ whereas the ASPECT $(p=0.417)$ and mRS $(p=0.240)$ scores were found to have no correlation with AF.

In 17 of the patients (about 18\%) treated with IV tPA, procedure-related complications occurred in the form of major or minor bleeding. Eight of them were major complications such as lobar hematoma and subarachnoid hemorrhage and nine were minor complications such as cerebral hemorrhage.
Table II: The mRS scores of the patients with and without various risk factors for ischemic stroke in the third month

\begin{tabular}{|c|c|c|c|c|c|}
\hline & & $\mathbf{N}$ & Mean & $\begin{array}{l}\text { Std. } \\
\text { Deviati } \\
\text { on }\end{array}$ & $\mathbf{p}$ \\
\hline \multirow{3}{*}{ HT } & Yes & 54 & 4.06 & 1.76 & \\
\hline & No & 41 & 3.33 & 1.82 & 0.076 \\
\hline & Yes & 23 & 4.14 & 1.61 & \\
\hline \multirow[t]{2}{*}{ DM } & No & 72 & 3.62 & 1.87 & 0.240 \\
\hline & Yes & 46 & 3.17 & 1.60 & \\
\hline \multirow[t]{2}{*}{ HL } & No & 49 & 3.80 & 1.83 & 0.435 \\
\hline & Yes & 38 & 4.43 & 1.83 & \\
\hline \multirow[t]{2}{*}{ CAD } & No & 57 & 3.62 & 1.79 & 0.131 \\
\hline & Yes & 35 & 3.52 & 1.72 & \\
\hline \multirow[t]{2}{*}{ HF } & No & 60 & 3.90 & 1.91 & 0.362 \\
\hline & Yes & 55 & 2.33 & 0.82 & \\
\hline \multirow[t]{2}{*}{ Smoking } & No & 40 & 4.75 & 1.49 & 0.008 \\
\hline & Yes & 32 & 3.57 & 1.83 & \\
\hline \multirow[t]{2}{*}{ TR } & No & 63 & 3.09 & 1.59 & 0.323 \\
\hline & Yes & 37 & 3.46 & 1.70 & \\
\hline \multirow[t]{2}{*}{ MVR } & No & 58 & 3.21 & 1.74 & 0.546 \\
\hline & Yes & 51 & 4.07 & 1.72 & \\
\hline AF & No & 44 & 3.32 & 1.85 & 0.063 \\
\hline
\end{tabular}

HT: hypertension, DM: Diabetes mellitus, HL: Hyperlipidemia, CAD: Coronary artery disease, HF: Heart failure, TR: Tricuspid regurgitation, MVR: Mitral valve regurgitation, AF: Atrial fibrillation

Furthermore, hemi orolingual angioedema developed in one patient. During the follow-up period, mortality was observed in $14(15 \%)$ of the patients. Of these, six (6.3\%) were caused by cerebral hemorrhage due to treatment complications and eight $(8.4 \%)$ were due to other systemic complications. The complication rate was found to be higher in patients with low ASPECT scores, high LDL, and total cholesterol levels and smokers $(\mathrm{p}=0.038, \mathrm{p}=0.016, \mathrm{p}=0.019$, and $\mathrm{p}=0.041$, 
respectively) (Table III). Furthermore, as expected, mRS scores were significantly higher in patients who developed complications $(\mathrm{p}=0.004)$. Logistic regression analysis revealed that only the ASPECT score from factors that we found to be effective on the risk of developing complications was a highly effective factor in the development of complications (Table IV).

Table III: Comparison of patients with and without tPA-related bleeding complications

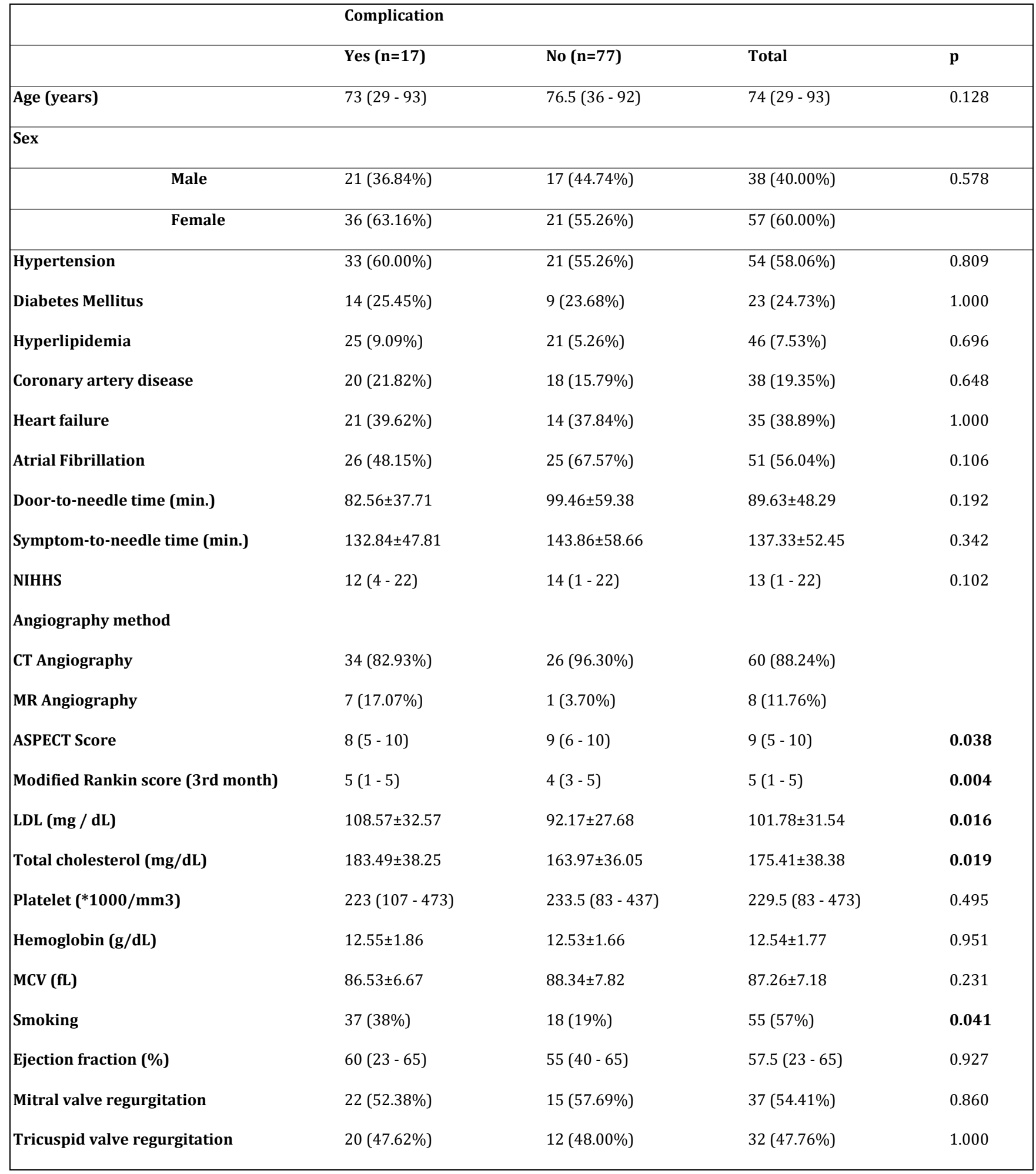


CT: computed tomography, MR: magnetic resonance, NIHSS: National institute health scale score, ASPECT: Alberta Stroke Program Early CT Scores, MCV: mean corpuscular volume, LDL: low density lipoprotein.

Table IV: Logistic regression analysis of factors associated with the development of tPA-related bleeding complications

\begin{tabular}{|lllllll|}
\hline \multicolumn{1}{c}{ B } & S.E. & OR & p & \multicolumn{2}{c|}{ 95\% confidence interval } \\
\hline $\begin{array}{l}\text { ASPECT score at the time of } \\
\text { admission }\end{array}$ & -0.588 & 0.403 & 2.131 & $\mathbf{0 . 0 3 4}$ & 0.252 & 1.223 \\
LDL level & 0.015 & 0.035 & 0.174 & 0.677 & 0.947 & 1.087 \\
Total cholesterol level & 0.005 & 0.028 & 0.028 & 0.867 & 0.950 & 1.062 \\
Constant & 5.495 & 3.912 & 1.973 & 0.160 & & \\
\hline
\end{tabular}

\section{DISCUSSION}

Time is the most important factor affecting the success of IV thrombolytic therapy in ischemic cerebrovascular diseases. Previous studies have shown that about two million neurons and 14 billion synapses disappear every minute until reperfusion is achieved ${ }^{16}$. Considering this data, the importance of time in ischemic stroke can be understood once again. Although the time frame for tPA treatment in the NINDS study was limited to three hours ${ }^{4}$, ECASS III has shown that tPA therapy administered within four and a half hours has positive effects on morbidity without causing severe complications ${ }^{5}$. In relation to these results, it is recommended that stroke patients should be identified early, and the door-toneedle time should not exceed 60 minutes in 112 emergency departments and hospital emergency departments. In the present study, the mean door-to-needle time was $89 \mathrm{~min}$ and the symptom-toneedle time was 137 minutes. These results were compatible with other studies conducted in Turkey. According to data by the Turkish Thrombolysis Therapy Study Group, these times were 69 and 150 minutes, respectively ${ }^{17}$. Data we obtained and those published in Turkey are not as close to the targeted door-to-needle time of 60 minutes, meaning that more importance should be attached to the training of emergency medical personnel to increase awareness of thrombolytic therapy in our region and Turkey and that awareness of the symptoms and treatment of the disease should be raised in the society. Furthermore, regarding the time frame of treatment, the symptom-toneedle time has been shown to be an effective and important factor in clinical recovery in different studies investigating the effect of symptom--to-needle time on prognosis ${ }^{18,19}$. However, in a study by Oruç et al. $^{20}$, no relationship was reported between symptom-to-needle time and mRS scores at the end of the third month. Similar to this study, we could not find a significant relationship between door-toneedle time, symptom-to-needle time, and $\mathrm{mRS}$. We believe that these results may be due to the small number of patients, factors such as age, NIHSS, ASPECT and comorbidity burden that are effective in determining prognosis, as well as the presence of anastomosis that provides microcirculation.

Various complications of IV tPA therapy have been reported in previous studies, however, intracerebral hemorrhage is the most feared complication following this therapy. Although the frequency of development of hemorrhage complications varies from center to center, the incidences of symptomatic intracranial hemorrhage have been reported to be $6.4 \%, 2.4 \%$, and $7 \%$ in the NINDS trial, ECASS-III, and Alteplase Thrombolysis for 
Acute Noninterventional Therapy in Ischemic Stroke (ATLANTIS-B), respectively $4,5,21$. In a study by Yaghi et al. ${ }^{22}$, the incidence of intracerebral hemorrhage due to IV tPA treatment was found to be $3.3 \%$ and hemorrhage-related mortality was $52.3 \%$. In a study from Turkey, Kutluk et al. ${ }^{17}$ reported that the incidence of hemorrhage due to IV tPA therapy was $22 \%$ and that $30 \%$ of all mortalities were due to bleeding complications. The results of the present study were compatible with this study. While tPA-related intracranial hemorrhage was observed in $18 \%$ of our patients (minor bleeding rate was $9.4 \%$, major bleeding rate was $8.4 \%$ in all patients), $42.8 \%$ of all mortalities were found to be due to bleeding complications tPA. As can be understood from these data, the rate of tPA-related bleeding complications in Turkey is slightly higher than the rates in developed countries. We believe that this may be due to the less tPA application frequency in Turkey, longer time to reach the centers where tPA is applied due to the lack of awareness of this treatment in the community, and many other reasons, such as genetic factors. Furthermore, hemi orolingual angioedema, which is a very rare complication, has developed in one of our cases following tPA other than bleeding but full recovery has been achieved in this patient with the necessary treatment. Another finding obtained from the present study is that the rate of treatment-related complications is higher in patients with higher ASPECT scores, LDL, and total cholesterol levels and smokers. However, the logistic regression analysis has shown that only low ASPECT scores of these factors have a significant effect on the development of intracranial hemorrhage. This finding is compatible with the literature. In NINDS and ECASS-II trials, the rate of intracranial hemorrhage has been reported to be relatively higher in patients with an ASPECT score of 7 and below ${ }^{4,23,24}$.

As it is known, DM and HT are definite risk factors that can be altered in ischemic stroke 25,26 . The HT can cause a predisposition to large artery occlusion and embolism and even a large arterial occlusion and even cause obstructive atherosclerosis, leading to lacunar infarction. In previous studies, it has been reported that $75 \%$ of patients with ischemic stroke have HT. This rate was $56 \%$ in the present study ${ }^{27}$. Like HT, DM is another systemic disease that has been shown to increase the risk of ischemic stroke. Previous studies have shown that the presence of DM increases the risk of ischemic stroke by two to six times ${ }^{28}$. Interestingly, the presence of DM, HT, HL, and CAD, which are considered as definitive risk factors for ischemic stroke, $\mathrm{HF}$, which is one of the possible risk factors, and other factors such as heart valve problems (MVR, TR) has been found to have no significant effect on $\mathrm{mRS}$ at the end of the third month. Furthermore, we found no statistically significant relationship between the mRS scores and door-to-needle time, symptom-to-needle time, and NIHSS scores and ASPECT scores at the time of admission. Unlike the literature, the fact that we could not find a significant relationship between the mRS scores and symptom-to-needle time and NIHSS scores may be due to the low number of patients. Nonvalvular AF is a disease associated with the most important risk of cardiogenic embolism in advanced age. The presence of AF independently increases the risk of stroke four to five times. At least $15-20 \%$ of all ischemic strokes develop directly due to $\mathrm{AF}$, independent of other factors. Even in cases with both $\mathrm{AF}$ and stroke, riskcausing comorbidities such as HT, DM, and coronary heart disease are also more common in stroke patients. Therefore, the prognosis of stroke is worse in stroke 
patients with $\mathrm{AF}^{29,30}$. Compatible with this data, patients with AF included in the present study had higher NIHSS scores, however, we found no relationship between the presence of AF and mRS.

In conclusion, the results of the present study, in which general data on tPA treatment applied in our clinic since 2015 has been presented, has been shown to be compatible with the literature. However, the awareness and application frequency of this treatment is still not sufficient throughout the world and particularly in Turkey. Although there is an increase in the number of patients receiving tPA in our clinic every year, we aim to increase awareness clinically and to expand the use of IV thrombolytic therapy in selected patients.

Ethics Committee Approval: Ethical approval for this study was obtained from Bolu Abant Izzet Baysal University Clinical Researches Ethic Committee Approval (Date: 29/02020, Decision No: 2020/231).

Declaration of Conflicting Interests: The authors declare that they have no conflict of interest.

Financial Disclosure: No financial support was received.

\section{REFERENCES}

1. Guzik A, Bushnell C. Stroke Epidemiology and Risk Factor Management. Continuum (Minneap Minn). 2017; 23: 15-39.

2. Ozdemir O, Giray S, Arlier Z, et al. Predictors of a Good Outcome after Endovascular Stroke Treatment with Stent Retrievers. ScientificWorldJournal. 2015; 2015: 403726.

3. Ozdemir O, Beletsky V, Chan R, et al. Thrombolysis in patients with marked clinical fluctuations in neurologic status due to cerebral ischemia. Arch Neurol. 2008; 65: 1041-3.

4. National Institute of Neurological Disorders, Stroke rt-PA Stroke Study Group. Tissue plasminogen activator for acute ischemic stroke. N Engl J Med. 1995; 333: 1581-7.
5. Hacke $W$, Kaste $M$, Bluhmki E, et al. Thrombolysis with alteplase 3 to 4.5 hours after acute ischemic stroke. N Engl J Med. 2008; 359: 1317-29.

6. Kutlu K. Akut iskemik inmede intravenöz trombolitik tedavi: Sorumluluğumuzun farkında mıyız? Turk Serebrovaskuler Hast Derg. 2009; 15: 35-9.

7. Topcuoglu Ma $\mathrm{CH}$, Saribas O. Akut iskemik inmede trombolitik tedavi. Turk J Neurol. 1997; 3: 111-9.

8. H Cabalar, M. Tasdemir N, Erdogan H.A, et al. Akut İskemik İnmede İntravenöz Trombolitik Tedavi Deneyimlerimiz. Bakirkoy Tip Derg. 2018; 14: 71-5.

9. Çetiner M, Canbaz Kabay S, Aydin HE. Intravenous Thrombolytic Therapy in Acute Ischemic Stroke: The Experience of Kütahya. Turk J Neurol. 2017; 23: 193-8.

10. Tanriverdi Z, Necioglu Orken D, Aksoy S, et al. Intravenous thrombolytic theraphy in acute stroke: the experience of the neurology department of sisli etfal education and research hospital. SETB. 2012; 46: 165-9.

11. Karakaş MS, Özbek SC, Er A, et al. Right heart thrombus entrapped in patent foramen ovale with pulmonary embolism in a patient with primary hypercoagulable state. Dicle Med J. 2012; 39: 440-444

12. Yasar A, Basar N, Kasapkara A, et al. Impact of metabolic syndrome on ST segment resolution after thrombolytic therapy for acute myocardial infarction. Dicle Med J. 2010; 37: 276-81.

13. Barber PA, Demchuk AM, Zhang J, et al. Validity and reliability of a quantitative computed tomography score in predicting outcome of hyperacute stroke before thrombolytic therapy. ASPECTS Study Group. Alberta Stroke Programme Early CT Score. Lancet. 2000; 355: 1670-4.

14. Jauch EC, Saver JL, Adams HP, Jr. et al. Guidelines for the early management of patients with acute ischemic stroke: a guideline for healthcare professionals from the American Heart Association/American Stroke Association. Stroke. 2013; 44: 870-947. 
15. Bonita R, Beaglehole R. Recovery of motor function after stroke. Stroke. 1988; 19: 1497500.

16. Saver JL. Time is brain--quantified. Stroke. 2006; 37: 263-6.

17. Kutluk K, Kaya D, Afsar N, et al. Analyses of the Turkish National Intravenous Thrombolysis Registry. J Stroke Cerebrovasc Dis. 2016; 25: 1041-7.

18. Wardlaw JM, Murray V, Berge E, et al. Thrombolysis for acute ischaemic stroke. Cochrane Database Syst Rev. 2014; CD000213.

19. Azzimondi G, Bassein L, Fiorani L, et al. Variables associated with hospital arrival time after stroke: effect of delay on the clinical efficiency of early treatment. Stroke. 1997; 28: 537-42.

20. Oruç S, Yilmaz Küsbeci Ö, Akpinar Oruç O, et al. A year's retrospective evaluation of patients hospitalized with the diagnosis of ischemic stroke at Kocatepe University Medicine Faculty Neurology Clinic. Türk Beyin Damar Hast Derg. 2014; 20: 94-8.

21. Clark WM, Wissman S, Albers GW, et al. Recombinant tissue-type plasminogen activator (Alteplase) for ischemic stroke 3 to 5 hours after symptom onset. The ATLANTIS Study: a randomized controlled trial. Alteplase Thrombolysis for Acute Noninterventional Therapy in Ischemic Stroke. JAMA. 1999; 282: 2019-26.

22. Yaghi S, Boehme AK, Dibu J, et al. Treatment and Outcome of Thrombolysis-Related Hemorrhage: A Multicenter Retrospective Study. JAMA Neurol. 2015; 72: 1451-7.
23. Hill MD, Rowley HA, Adler F, et al. Selection of acute ischemic stroke patients for intraarterial thrombolysis with pro-urokinase by using ASPECTS. Stroke. 2003; 34: 1925-31.

24. Hacke W, Kaste $M$, Fieschi $C$, et al. Randomised double-blind placebo-controlled trial of thrombolytic therapy with intravenous alteplase in acute ischaemic stroke (ECASS II). Second European-Australasian Acute Stroke Study Investigators. Lancet. 1998; 352: 124551.

25. Aluçlu MU, Yücel Y. Serebellar İnfarktlarda Etyoloji, Lokalizasyon ve Prognoz. Dicle Med J. 2006; 33: 31-5.

26. Öztürk Ü, Öztürk PA, Asena M. Akut İnmede Risk Faktörü ve Prognoz Üzerine Etkisi ile Magnezyum. Dicle Med J. 2019; 46: 781-7.

27. Romero JR, Morris J, Pikula A. Stroke prevention: modifying risk factors. Ther Adv Cardiovasc Dis. 2008; 2: 287-303.

28. Abbott RD, Donahue RP, Macmahon SW, et al. Diabetes and the risk of stroke. The Honolulu Heart Program. JAMA. 1987; 257: 949-52.

29. Steger C, Pratter A, Martinek-Bregel M, et al. Stroke patients with atrial fibrillation have a worse prognosis than patients without: data from the Austrian Stroke registry. Eur Heart J. 2004; 25: 1734-40.

30. Lamassa M, Di Carlo A, Pracucci G, et al. Characteristics, outcome, and care of stroke associated with atrial fibrillation in Europe: data from a multicenter multinational hospital-based registry (The European Community Stroke Project). Stroke. 2001; 32: 392-8. 